\title{
PENINGKATAN HASIL BELAJAR MODEL COMPLETE SENTENCE MUATAN BAHASA INDONESIA DI SDN 027 SAMARINDA ULU
}

\author{
Nurul Hikmah ${ }^{1}$, Eka Selvi Handayani ${ }^{2}$, Hani Subakti ${ }^{3}$ \\ Universitas Widya Gama Mahakam Samarinda ${ }^{1}$, Universitas Widya Gama Mahakam \\ Samarinda ${ }^{2}$, Universitas Widya Gama Mahakam Samarinda ${ }^{3}$ \\ Pos-el: nurulhikmah@uwgm.ac.id ${ }^{1}$, ekaselvi@uwgm.ac.id ${ }^{2}$, hanisubakti@uwgm.ac.id ${ }^{3}$
}

\begin{abstract}
ABSTRAK
Penelitian tindakan kelas (PTK) sangat penting dilaksanakan untuk mengetahui hasil belajar siswa. Ini dilatarbelakangi oleh hasil belajar siswa yang kurang memuasakan khususnya pada muatan bahasa Indonesia pada kurikulum 2013. Atas dasar itu, penelitian ini dilaksanakan untuk mengukur peningkatan hasil belajar model complete sentence muatan bahasa Indonesia di SDN 027 Samarinda Ulu. Subjek dalam penelitian ini adalah siswa kelas III yang berjumlah 30 siswa. Penelitian telah dilaksanakan sebanyak dua siklus. Tahap pelaksanaan disetiap siklus terdiri dari atas perencanaan, pelaksanaan, pengamatan, dan refleksi diakhir tindakan. Teknik pengumpulan data menggunakan observasi, tes, wawancara, dan dokumentasi. Adapun hasil akhir dari penelitian tindakan kelas (PTK) menunjukan bahwa telah terjadi peningkatan hasil belajar siswa yang cukup signifikan. Ini terlihat dari hasil siklus I yang mendapatkan nilai ratarata tes yaitu 70. Sedangkan pada siklus II hasil belajar siswa lebih meningkat dengan mendapatkan nialai rata-rata tes 80. Berdasarkan hasil penelitian tindakan kelas (PTK), maka dapat disimpulkan bahwa complete sentence dapat meningkatkan hasil belajar muatan bahasa Indonesia siswa kelas III SDN 027 Samarinda Ulu tahun pembelajaran 2019/2020.
\end{abstract}

Kata Kunci: Hasil Belajar, Complete Sentence, Muatan Bahasa Indonesia.

\begin{abstract}
Class action research (CAR) is very important to know students ' learning outcomes. This is backed by the learning outcomes of students who are less pronounced especially in the Indonesian language content in the 2013 curriculum. On that basis, this study was conducted to measure the improvement of learning outcomes of complete sentence model of Indonesian language content at SDN 027 Samarinda Ulu. The subject in this study was a grade III student numbering 30 students. Studies have been implemented in as many as two cycles. The implementation phase of each cycle consists of the above planning, implementation, observation, and reflection at the end of the action. Data collection techniques using observation, tests, interviews, and documentation. The final outcome of class action research (CAR indicates that there has been a significant increase in student learning outcomes. This is seen from the I cycle results that get the average test rate of 70 . While in cycle II students learn more increased by obtaining an average Nialai test 80 . Based on the results of the class action research $(C A R)$, it can be concluded that complete sentence can improve the results of Indonesian language content of grade III students at SDN 027 Samarinda Ulu learning year $2019 / 2020$.
\end{abstract}

Keywords: Learning Outcomes, Complete Sentence, Indonesian Language Content. 


\section{PENDAHULUAN}

Pendidikan merupakan usaha dasar dan terencana untuk mewujudkan dan melahirkan manusia sebagai peserta didik dalam suasana pembelajaran agar peserta didik secara aktif mengembangkan potensi dirinya sehingga memiliki kekuatan spiritual keagamaan, kepribadian, pengendalian diri sebagai manusia kepribadian, pengendalian diri sebagai manusia kepribadian, kecerdasan, keterampilan, akhlak yang berguna bagi masyarakat bangsa dan negara (Chomaidi \& Salmah, 2018). Pendidikan di sekolah selalu berhubungan dengan proses kegiatan pembelajaran di kelas dan tidak lepas dari interaksi antara guru dengan siswa, dalam pembelajaran guru merupakan komponen terpenting dalam mencapai keberhasilan pembelajaran dan peningkatan hasil pembelajaran di kelas.

Guru merupakan orang yang bertanggung jawab terhadap perkembangan peserta didik dengan mengupayakan perkembangan seluruh potensinya, baik potensi kognitif, potensi afektif, maupun potensi psikomotorik (Zahroh, 2015). Guru merupakan fasilitator dan motivator di kelas pada proses belajar mengajar untuk tercapainya hasil belajar siswa, untuk mencapai keberhasilan mengajar di kelas guru harus pintar dalam memilih model yang tepat pada proses mengajarnya sehingga peserta didik mudah dalam menerima pembelajaran yang diajarkan guru pada saat pembelejaran. Peran penting guru juga harus pintar dalam menguasai dan mengembangkan materi ajar, menyiapkan pelajaran, mengontrol dan mengevaluasi kegiatan siswa setiap hari. Sangatlah penting bagi pendidik untuk memahami karakteristik materi dan peserta didik dalam pemilihan model-model pembelajaran yang tepat.

Model pembelajaran adalah suatu rencana atau pola yang dapat digunakan untuk membentuk kurikulum, merancang bahan-bahan pembelajaran, dan membimbing pembelajaran di kelas atau yang lain (Rusman, 2014). Model pembelajaran juga bentuk pembelajaran yang tergambar dari awal sampai akhir yang disajikan secara khas oleh pendidik atau bingkai dari penerapan suatu pendekatan, strategi, metode, dan teknik, maka peneliti akan menerapkan model pembelajaran yang inovatif yaitu model pembelajaran complete sentence.

Berdasarkan hasil observasi yang peneliti lakukan di kelas III C SDN 027 Samarinda Ulu pada saat proses pembelajaran di kelas masih sering ditemukan adanya siswa yang tidak aktif di kelas pada saat jam pembelajaran. Pada saat pembelajaran berlangsung di kelas guru menjelaskan siswa tidak mau bertanya setelah guru menjelaskan, tetapi ketika guru kembali bertanya kepada siswa tentang materi yang masih belum dimengerti siswa lebih banyak diam, guru mengetahui siswa masih belum mengerti tentang materi yang diajarkan setelah guru memberikan tes kepada siswa, masih banyak siswa yang nilainya rendah.

Di SDN 027 Samarinda Ulu banyak upaya yang bisa digunakan untuk meningkatan hasil belajar siswa, salah satunya dalam muatan Bahasa Indonesia di kelas III. Dapat dilihat dari nilai siswa dari hasil belajar muatan bahasa Indonesia di bawah kriteria ketuntasan minimum (KKM). Kriteria ketuntasan minimal (KKM) yang sudah ditetapkan oleh guru kelas yaitu 75, siswa yang mendapatkan nilai di bawah 75 dikatakan tidak tuntas.

Sebagai guru harus pintar dalam melakukan pendekatan kepada siswanya supaya guru dapat mengetahui karakter siswanya dan kemampuan siswa, karena karakter siswa dan kemampuan siswa itu berbeda-beda tiap individu. Dalam muatan bahasa Indonesia pendidik bisa menggunakan model-model pembelajaran yang tepat sesuai dengan materi pembelajaran, salah satunya adalah model pembelajaran complete 
sentence. Model pembelajaran complete sentece adalah suatu model pembelajaran yang sederhana di mana siswa melengkapi kalimat paragrap yang rumpang dengan tepat. Model pembelajaran complete sentence bisa digunakan oleh guru untuk melihat ketelitian dan mencermati kalimat dengan baik dalam mencari jawaban.

Tujuan dari penelitian adalah untuk mengetahui peningkatan hasil belajar siswa dengan model pembelajaran complete sentence pada muatan bahasa Indonesia di kelas III C SDN 027 Samarinda Ulu Tahun Pembelajaran 2019/2020. Adapun manfaat penelitian ini untuk meningkatkan hasil belajar peserta didik pada muatan bahasa Indonesia dengan model pembelajaran complete sentence, menambah kecerdasan peserta didik dalam mencermati kalimat bahasa yang baik dan benar, peserta didik mampu mengikuti pembelajaran di kelas dengan aktif.

Belajar merupakan kegiatan penting setiap orang, termasuk di dalamnya belajar ialah suatu proses yang dilakukan individu untuk memperoleh suatu perubahan tingkah laku yang baru secara keseluruhan, sebagai hasil pengalaman individu itu sendiri di dalam interaksi dengan lingkungannya (Aunurrahman, 2014). Dimyati \& Mudjiono (2015) belajar adalah sesuatu perilaku pada saat orang belajar, maka respons menjadi lebih baik. Sebaiknya, bila ia tidak belajar maka responsnya menurun, dalam belajar ditemukan adanya kesempatan terjadinya peristiwa yang menimbulkan respons pebelajar. (Dimyati \& Mudjiono, 2015) belajar merupakan kegiatan yang kompleks hasil belajar berupa kapabilitas, Setelah belajar orang memiliki ketrampilan, pengetahuan, sikap, dan nilai. Timbulnya kapabilitas itu tersebut adalah dari stimulasi yang berasal dari lingkungan, dan proses kognitif yang dilakukan oleh pembelajar.
Suardi (2018) belajar sebagai perubahan tingkah laku pada diri individu dan individu dengan lingkungan nya. Unsur utama dari belajar adalah terjadinya perubahan pada seseorang. Menurut dari beberapa para ahli peneliti dapat menyimpulkan bahwa belajar merupakan perubahan prilaku sebagai hasil pengalaman tiap individu, kebiasaan-kebiasaan dan dari lingkungan sekitar.

Belajar memiliki tujuan untuk mencapai tindakan instruksional yang dinamakan instructional effects yang biasanya berbentuk pengetahuan dan ketrampilan (Thobroni, 2015). Anak didik mempunyai tujuan, unsur lainya sebagai pengantar dan pendukung. Ada suatu prosedur jalanya interaksi yang direncanakan, disain untuk mencapai tujuan yang telah ditetapkan. Agar tetap dapat mencapai tujuan secara optimal, maka dalam melakukan interaksi perlu ada prosedur atau langkah-langkah sistematik dan relevan.

Untuk mencapai tujuan pembelajaran yang satu dengan yang lain, mungkin akan membutuhkan prosedur dan desain yang berbeda pula. Sebagai contoh misalnya tujuan pembelajaran agar anak didik dapat menunjukan letak Kota New York tentu kegiatan tidak cocok kalau anak didik disuruh membaca dalam hati, dan begitu seterusnya (Dimyati \& Mudjiono, 2015)

Belajar merupakan tindakan dan perilaku siswa yang kompleks. Sebagai tindakan, maka belajar hanya dialami oleh siswa sendiri. Siswa adalah penentu terjadinya proses belajar. Proses belajar terjadi berkat siswa memperoleh sesuatu yang ada di lingkungan sekitar. Lingkungan yang dipelajari oleh siswa berupa keadaan alam, benda-benda, hewan, tumbuh-tumbuhan, manusia, atau hal-hal yang dijadikan bahan belajar. Tindakan belajar tentang suatu hal tersebut tampak sebagai perilaku belajar yang tampak dari luar (Dimyati \& Mudjiono, 2015). 
Hasil belajar merupakan polapola perbuatan, nilai-nilai pengertianpengertian, sikap-sikap, apresiasi, dan keterampilan (Thobroni, 2015). Dimyati \& Mudjiono (2015) Hasil belajar adalah proses untuk melihat sejauh mana siswa dapat menguasai pembelajaran setelah mengikuti kegiatan proses belajar mengajar atau keberhasilan yang dicapai seorang peserta didik setelah mengikuti pembelajaran yang ditandai dengan bentuk angka, huruf atau simbol tertentu yang disepakati oleh pihak penyelenggara pendidikan.

Tampubolon (2014) hasil belajar adalah kemampuan yang diperoleh anak setelah melalui kegiatan belajar, belajar itu sendiri merupakan suatu proses dari seseorang yang berusaha memperoleh bentuk perubahan perilaku yang relative menetap. Rusman (2014) hasil belajar adalah sejumlah pengalaman yang diperoleh siswa yang mencakup ranah kognitif, afektif dan psikomotorik, belajar tidak hanya penguasaan konsep teori mata pelajaran saja tapi juga penguasaan kebiasaan, persepsi, kesenangan, minat bakat, penyesuaian sosial, macam keterampilan, cita-cita, keinginan, dan harapan. Berdasarkan pendapat para ahli di atas dapat disimpulkan bahwa hasil belajar adalah kemampuan-kemampuan peserta didik setelah menerima pengalaman belajarnya.

Pembelajaran tematik merupakan salah satu model pembelajaran dalam pembelajaran terpadu yang merupakan suatu sistem pembelajaran yang memungkinkan siswa, baik secara individu maupun kelompok, aktif menggali dan menemukan konsep serta prinsip-prinsip keilmuan secara holistik, bermakna, dan autentik (Rusman, 2014). Prastowo (2019) bahwa model pembelajaran tematik ialah pembelajaran yang dirancang berdasarkan tema-tema tertentu, dalam pembahasannya, tema itu ditinjau dari berbagai mata pelajaran. Pembelajaran tematik sebagai model pembelajaran termasuk salah satu tipe atau jenis daripada model pembelajaran terpadu yang menggunakan tema untuk mengaitkan beberapa mata pelajaran sehingga dapat memberikan pengalaman bermakna kepada siswa (Trianto, 2011)

Pembelajaran tematik adalah pembelajaran terpadu yang menggunakan tema untuk mengaitkan beberapa mata pelajaran sehingga dapat memberikan pengalaman bermakna kepada peserta didik (Malawi 2019). Menurut beberapa para ahli disimpulkan bahwa pembelajaran tematik merupakan pembelajar yang di dalamnya banyak muatan pembelajaran tidak hanya satu yang mengajarkan siswa untuk aktif di kelas.

Pembelajaran bahasa Indonesia diarahkan untuk meningkatkan kemampuan peserta didik. Bahasa Indonesia merupakan penunjang keberhasilan dalam mempelajari semua mata pelajaran. Pembelajaran bahasa diharapkan dapat membantu peserta didik mengenal dirinya, budayanya, dan budaya orang lain. Siswa diharapkan mampu menggunakan bahasa Indonesia yang baik untuk mengemukakan gagasan atau perasaan dan berpartisipasi dalam masyarakat (Anisatun 2018).

Pembelajaran bahasa Indonesia diarahkan untuk meningkatkan kemampuan peserta didik untuk berkomunikasi dalam bahasa Indonesia dengan baik dan benar, baik secara lisan maupun tulisan serta menumbuhkan kualifikasi kemampuan minimal peserta didik yang menggambarkan penguasaan pengetahuan, keterampilan berbahasa, dan sikap positif terhadap bahasa dan sastra Indonesia. Pembelajaran bahasa Indonesia di sekolah dasar terdiri dari empat keterampilan, yaitu membaca, menulis, menyimak, dan berbicara.

Model pembelajaran adalah kerangka konseptual yang melukiskan prosedur sistematis dalam mengorganisasikan pengalaman belajar peserta didik untuk mencapai tujuan 
belajar tertentu, dan fungsi sebagai pedoman bagi perancang pembelajaran serta pendidik dalam merancangkan dan melaksanakan pembelajaran (Tampubolon, 2014). Model pembelajaran adalah suatu rencana pelaksanaan pembelajaran yang didesain secara sistematis untuk mendukung pembelajaran guna memberikan pengalaman belajar kepada siswa dalam rangka mencapai tujuan pembelajaran (Jalil, 2018)

Model pembelajaran merupakan suatu perencanaan atau suatu pola yang digunakan sebagai pedoman dalam merencanakan pembelajaran di kelas (Jumaidi, 2018). Model pembelajaran dapat dijadikan pola pilihan,artinya para guru boleh memilih model pembelajaran yang sesuai dan efisien untuk mencapai tujuan pendidikannya (Rusman, 2014). Menurut pendapat beberapa para ahli dapat disimpulkan model pembelajaran sebagai rangkaian dan rencana dalam proses pembelajaran yang sistematis untuk mencapai tujuan belajar yang diharapkan dan mendapat pengalaman belajar.

Pembelajaran

complette

Ssentence adalah model pembelajaran yang mengarahkan siswa belajar melengkapi paragraf yang belum sempurna dengan menggunakan kunci jawaban yang tersedia (Shoimin, 2017). Tampubolon (2014) pembelajaran complete sentence adalah metode melengkapi kalimat suatu paragraf yang belum lengkap.

Langkah-langkah kegiatan pembelajaran complette sentence adalah sebagai berikut (1) Pendidik menyampaikan apa yang ingin dicapai, (2) pendidik menyampaikan materi secukupnya atau peserta disuruh membacakan buku atau modul dengan secukupnya, (3) Bentuk kelompok yang terdiri dari 2 atau 3 orang, (4) bagikan lembar kegiatan berupa paragraf yang kalimatnya belum lengkap, (5) Siswa berdiskusi untuk melengkapi kalimatnya belum lengkap, (6) siswa berdiskusi secara berkelompok, (7) Setelah jawaban yang telah diperbaiki benar, tiap-tiap siswa disuruh membaca berulang-ulang sampai mengerti atau hafal, dan (8) secara bersama-sama guru dan siswa menyimpulkan dan menutup.

\section{METODE PENELITIAN}

Jenis penelitian ini adalah penelitian tindakan kelas (PTK), penelitian tindakan kelas (PTK) adalah suatu penelitian yang dilakukan secara sistematis reflektif terhadap berbagai tindakan yang dilakukan oleh pendidik yang sekaligus sebagai peneliti, sejak disusunnya suatu perencanaan sampai penilaian terhadap tindakan nyata di dalam kelas yang berupa kegiatan belajar mengajar untuk memperbaiki kondisi pembelajaran yang dilakukan (Subyantoro, 2019). Penelitian ini dilaksanakan melalui beberapa proses yaitu siklus 1 dan siklus 2 . Setiap siklus memiliki 4 tahap yaitu, perencanaan, pelaksanaan, obsrevasi, dan refleksi. Sementara itu, dilaksanakannya penelitian tindakan kelas (PTK) di antaranya untuk meningkatkan kualitas pendidikan atau pengajaran yang diselenggarakan oleh peneliti itu sendiri, yang dampaknya diharapkan tidak ada lagi permasalahan yang mengganjal di kelas.

Tampubolon (2014) penelitian tindakan kelas adalah penelitian yang dilakukan oleh pendidik di dalam kelasnya sendiri melalui refleksi diri. Tujuannya adalah untuk memperbaiki kinerjanya sebagai pendidik, sehingga hasil belajar peserta didik menjadi meningkat dan, secara sistem, mutu pendidikan pada satuan pendidikan juga meningkat. Subyantoro (2019) mendefinisikan penelitian tindakan kelas sebagai suatu bentuk penelitian yang bersifat reflektif dengan melakukan tindakan-tindakan tertentu agar dapat memperbaiki dan meningkatkan praktikpraktik pembelajaran di kelas secara 
professional. Nurhafit \& Kurniawan (2017) bahwa penelitian tindakan kelas (PTK) merupakan tentang situasi sosial dengan maksud untuk meningkatkan kualitas tindakan di dalamnya. Seluruh proses mencakup; telaah, diagnosis, perencanaan, pelaksanaan, pemantauan, dan pengaruh yang menciptakan hubungan antara evaluasi diri dengan pengembangan. Dari beberapa pendapat para ahli di atas dapat disimpulkan Penelitian Tindakan Kelas (PTK) adalah penelitian yang di lakakukan untuk memecahkan suatu masalah pembelajaran untuk meningkatkan kemampuan belajar siswa.

Subjek penelitian ini pada siswa kelas IIIC di SDN 027 Samarinda Ulu yang berjumlah 30 siswa yang terdiri dari 10 siswa perempuan dan 20 siswa laki-laki. Penelitian ini dilaksanakan di kelas IIIC SDN 027 Samarinda Ulu pada semester genap tahun pembelajaran 2019/2020. Pada penelitian ini peneliti menggunakan dua siklus yaitu, siklus 1 dan siklus II, masing-masing siklus mempunyai tahap yaitu perencanaan, pelaksanaan, pengamatan, dan refleksi. Setiap siklus ada 3 kali pertemuan. Model siklus penelitian tindakan kelas ini adalah sebagai berikut:

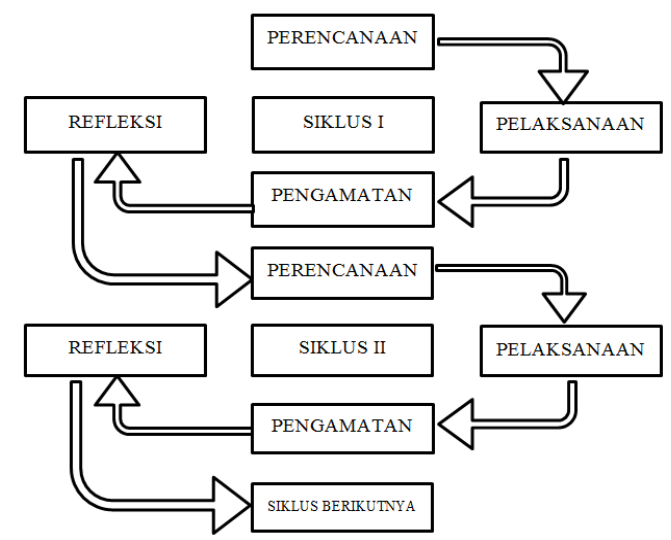

Gambar Siklus Penelitian (Arikunto : 2018)

1. Perencanaan

Pada tahap perencanaan peneliti dimulai menyusun perangkat pembelajaran yang akan dilaksanakan, hal-hal yang perlu dibuat oleh peneliti untuk perencanaan tersebut adalah :

a) Menyusun peragkat pembelajaran (RPP, bahan ajar)

b) Menyusun lembar observasi

c) Menentukan media pembelajaran dan alat evaluasi

2. Pelaksanaan

Pada tahap pelaksanaan peneliti melaksanakan pembelajaran menggunakan perangkat pembelajaran sesuai scenario pembelajaran dalam RPP dengan tahapan kegiatan awal, serta kegiatan inti dan kegiatan penutup. Peneliti juga melaksanakan penilaian atau tes siklus pertama. Kegiatan akhir untuk menarik kesimpulan, pemberian tugas, dan informasi materi pembelajaran lebih lanjut.

3. Observasi

$$
\text { Peneliti melakukan tahap }
$$
observasi atau pengamatan selama berlangsungnya kegiatan pembelajaran yang dilakukan oleh observer secara bersamaan pada saat pembelajaran berlangsung.

4. Refleksi

Data yang diperoleh saat observasi dianalisis sehingga memperoleh hasil refleksi kegiatan yang di dilakukan. Hasil dari analisis tersebut kemudian didapatkan kesimpulan untuk merencanakan siklus selanjutnya.

Pengumpulan data merupakan inti dari setiap penelitian Sugiyono (2019). Pada penelitian ini teknik pengumpulan data yang digunakan adalah observasi, wawancara terstruktur, tes, dokumentasi, dan keabsahan data:

a. Observasi Partisipatif

Observasi adalah pengumpulan data melalui pengamatan atas gejala, fenomena dan fakta empiris yang terkait dengan masalah penelitian. Teknik pengumpulan data dengan observasi digunakan bila, penelitian berkenan dengan perilaku manusia, proses kerja, gejala-gejala alam dan bila responden yang diamati tidak terlalu besar (Sugiyono, 2019). Dalam obserasi 
partisipatif ini peneliti terlibat dengan kegiatan sehari-hari orang yang sedang diamati atau yang digunakan sebagai sumber data penelitian. Sambil melakukan pengamatan, peneliti ikut melakukan apa yang dikerjakan oleh sumber data, dan ikut merasakan suka duka nya. Observasi partisipasi lengkap yang digunakan sebagai teknik pengumpulan data.

b. Wawancara Terstruktur

Wawancara merupakan teknik pengumpulan data di mana pewawancara (peneliti melakukan pengumpulan data) dalam mengumpulkan data mengajukan suatu pertanyaan kepada yang diwawancarai. Pada penelitian ini jenis wawancara terstruktur digunakan sebagai teknik pengumpulan data, oleh karena itu dalam melakukan wawancara, pengumpul data telah menyiapkan instrumen penelitian berupa pertanyaanpertanyaan tertulis yang alternative jawabannya pun telah disiapkan (Sugiyono, 2018)

c. Tes hasil belajar

Tes adalah cara yang digunakan atau prosedur yang ditempuh dalam rangka pengukuran dan penilaian di bidang pendidikan yang memberikan tugas dan serangkaian tugas yang diberikan oleh guru sehingga dapat dihasilkan nilai yang melambangkan prestasi peserta didik. Tes hasil belajar merupakan power test, maksudnya adalah mengukur kemampuan peserta didik dalam menjawab pertanyaan atau permasalahan (Sugiyono, 2019). Pengumpulan data dengan tes dilakukan dengan cara memberi sejumlah pertanyaan kepada subjek yang diteliti untuk dijawab, data hasil tes berupa angka. Tes yang digunakan ialah berbetuk soal isian sebanyak 10 nomor dengan masing masing nomor memiliki bobot 10 .

d. Dokumentasi

Dokumentasi menurut Sugiyono (2019) adalah suatu cara yang digunakan untuk memperoleh data dan informasi dalam bentuk buku, arsip, dokumen, tulisan angka dan gambar yang berupa laporan serta keterangan yang dapat mendukung penelitian. Dokumentasi digunakan untuk mengumpulkan data kemudian ditelaah. Dokumentasi yang dikumpulkan dalam penelitian ini ialah berupa RPP, nilai tes siswa, foto kegiatan, dan catatan harian.

e. Instrumen

Instrumen yang digunakan dalam penelitian ini bertujuan untuk memperoleh data kualitas pembelajaran, hasil belajar, dan tes soal kalimat rumpang.

Teknik analisis data pada penelitian ini menggunakan analisis data Kualitatif dan Kuantitatif. Analisis data dalam penelitian kualitatif dilakukan sejak sebelum memasuki lapangan, selama di lapangan, dan setelah selesai di lapangan. Sedangkan analisis data dalam penelitian kuantitatif menggunakan statistik deskriptif.

Teknik analisis data yang digunakan dalam penelitian ini adalah analisis data kualitatif yang dapat dianalisis secara deskriptif. Penelitian ini menggunakan rata-rata dan presentase yang akan diuraikan sebagai berikut:

Rata-rata digunakan untuk mengetahui hasil belajar dan peningkatan hasil belajar peserta didik dalam satu kelas. Penelitian ini menggunakan rata-rata dengan rumus:

$$
\begin{aligned}
& \bar{x}=\frac{\Sigma x}{n} \\
& \text { Keterangan: } \\
& \bar{x}=\text { rata-rata } \\
& \Sigma \mathrm{x}=\text { jumlah seluruh nilai peserta didik } \\
& \mathrm{n}=\text { jumlah peserta didik }
\end{aligned}
$$

Indikator keberhasilan adalah untuk mengetahui peningkatan dari hasil belajar, aktivitas siswa, dan ketrampilan. Penelitian akan dikatakan berhasil jika $80 \%$ jumlah siswa dalam muatan pembelajaran bahasa indonesia mendapatkan nilai >75 (KKM). Selain 
itu penelitian ini dikatakan berhasil Jika $80 \%$ jumlah siswa aktif dalam pembelajaran, dan $80 \%$ jumlah siswa mendapatkan nilai ketrampilan.

\section{HASIL DAN PEMBAHASAN}

Penelitian ini telah dilaksanakan sebanyak dua siklus secara konsisten. Masing-masing siklus terdiri dari 3 kali pertemuan. Pada masing-masing pertemuan berlangsung dilaksanakan selama 2x35 menit. Setiap memasuki pertemuan ketiga dilakukan tes untuk mengetahui peningkatan hasil belajar. Peneliti tealh terlebih dahulu melakukan observasi di kelas tersebut. Setelah dilakukan observasi, diperoleh data hasil belajar siswa. Diketahui bahwa hasil belajar siswa pada kondisi awal masih tergolong rendah dengan nilai rata-rata 60,5 .

\section{Siklus 1}

Pada siklus I terdiri dari 3 kali pertemuan, yaitu pertemuan pertama, kedua, dan ketiga. Waktu pembelajaran yang digunakan disetiap pertemuan adalah 70 menit, dengan keseluruhan waktu pembelajaran yang digunakan pada siklus I adalah 210 menit. Dalam penelitian ini, siklus I dilaksanakan dengan empat tahapan yaitu:

\section{1) Perencanaan}

Berdasarkan hasil nilai siswa pada semester I yang dilaksanakan sebelumnya, nilai bahasa Indonesia kelas $\mathrm{V}$ dari 30 siswa, yang mencapai kriteria ketuntasan minimal (KKM) yaitu 10 orang siswa (15.2\%). Sedangkan 20 orang $(84.8 \%)$ belum mencapai kriteria ketuntasan minimal (KKM).

2) Pelaksanaan

Pada tahap pelaksanaan ini dilakukan 3 kali pertemuan di mana pertemuan satu dan pertemuan kedua menyampaikan materi sedangkan pertemuan ketiga melakukan tes hasil belajar siswa. Selama pembelajaran ada beberapa masalah yang dihadapi pada siklus I siswa masih banyak bercerita di dalam kelas, tidak memperhatikan penjelasan guru, dan berjalan-jalan ke tempat duduk temannya.

Pertemuan kedua siklus I guru menggunakan complette sentence untuk menarik minat belajar dan motivasi belajar siswa dalam mengikuti pembelajaran. Namun hal yang sama masih terjadi, siswa pada pertemuan kedua masih ribut, tidak mau mendengar penjelasan guru dan sibuk mengobrol dengan temannya serta mengganggu temannya. Pada pertemuan ketiga siklus satu ini guru mengulang kembali materi yang disampaikan pada pertemuan satu dan dua sebelum melakukan tes. Hasil belajar siswa pada siklus I sudah tergolong cukup dengan nilai rata-rata 70.

\section{3) Wawancara}

Dari hasil wawancara yang dilakukan oleh peneliti, selama proses pembelajaran guru kelas belum pernah menggunakan complette sentence dalam kegiatan pembelajaran sehingga siswa merasa bosan, tidak berminat, dan tidak termotivasi dalam kegiatan pembelajaran tersebut.

4) Observasi

Hasil observasi siklus I pada pertemuan pertama, kedua, dan ketiga. Selama tiga kali pertemuan masih banyak masalah dan kendala yang dihadapi. Banyak siswa yang tidak mau bergabung dengan kelompok siswa lainnya, banyak siswa yang ribut, sehingga menciptakan suasana kelas yang kurang kondusif. Akibatnya siswa tidak dapat berkonsentrasi dengan baik.

5) Refleksi

Setelah melaksanakan kegiatan pembelajaran siklus I, kemudian peneliti melakukan refleksi terhadap proses kegiatan pembelajaran. Refleksi yang digunakan sebagai bahan pertimbangan melanjutkan kegiatan pembelajaran pada siklus II. Berdasarkan data-data yang diperoleh dapat disimpulkan bahwa dari hasil tes evaluasi diakhir siklus menunjukan bahwa hasil belajar pada 
siklus I yaitu dengan rata-rata 70 . Dari hasil tersebut menunjukan belum mencapai keriteria ketuntasan minimum (KKM) yaitu $\geq 75$ maka dari itu dilanjutkan pada siklus berikutnya.

\section{Siklus II}

Siklus II terdiri atas 3 kali pertemuan, yaitu pertemuan pertama, kedua, dan ketiga. Waktu pembelajaran yang digunakan disetiap pertemuan adalah 70 menit. Dengan keseluruhan waktu pembelajaran yang digunakan pada siklus II adalah 210 menit. Dalam penelitian ini, siklus II dilaksanakan dengan empat tahapan yaitu:

\section{1) Perencanaan}

Berdasarkan hasil refleksi pelaksanaan pada siklus I telah diketahui bahwa belum adanya peningkatan hasil belajar siswa dengan menggunakan complette sentence pada pembelajaran muatan bahasa Indonesia. Oleh, karena itu yang perlu dilakukan perencanaan pada siklus yang ke II. Peneliti akan memberikan arahan kembali pada siswa serta memperbaiki pengolahan kelas.

\section{2) Pelaksanaan}

Pada pelaksanaan ini dilakukan 3 kali pertemuan di mana pertemuan pertama dan kedua menyampaikan inti materi sedangkan pada pertemuan ketiga melakukan tes hasil belajar siswa. Selama pelaksanaan pembelajaran ada beberapa masalah yang dihadapi peneliti yaitu masih ada beberapa siswa yang sibuk berbicara dengan temannya pada saat guru menjelaskan. Akan tapi pada siklus ini siswa terlihat lebih siap dan aktif mengikuti pembelajaran dari pada pelaksanaan siklus I. Pada pertemuan kedua siklus kedua dilaksanakan guru melanjutkan materi dari pertemuan pertama dengan menggunakan complette sentence, siswa terlihat antusias dan bersemangat dalam belajar dan siswa terlihat lebih siap mengikuti pembelajaran. Pertemuan ketiga ini guru mengulang kembali materi yang disampaikan pada pertemuan satu dan dua sebelum melakukan tes. Berdasarkan tabel dapat diketahui hasil belajar siswa pada siklus II sudah tergolong baik dengan nilai rata-rata 80 .

3) Wawancara

Dari hasil wawancara yang dilakukan oleh peneliti, selama belajar guru kelas belum menggunakan spinning wheel dalam kegiatan pembelajaran sehingga siswa merasa bosan, tidak berminat, dan tidak termotivasi dalam kegiatan pembelajaran tersebut.

4) Observasi

Hasil dari observasi pada siklus II pertemuan pertama, pertemuan kedua, dan pertemuan ketiga selama pertemuan disiklus ini siswa terlihat lebih semangat dan siap dalam mengikuti kegiatan pembelajaran yang sedang berlangsung. Kemudian peneliti melanjutkan dengan menjelaskan materi.

5) Refleksi

Setelah melaksanakan kegiatan pembelajaran pada siklus II, kemudian peneliti melakukan refleksi terhadap proses kegiatan pembelajaran. Refleksi ini digunakan sebagai bahan pertimbangan untuk melanjutkan kegiatan pembelajaran. Berdasarkan data-data yang diperoleh, peneliti dapat menyimpulkan bahwa dari hasil tes evaluasi diakhir siklus ini menunjukan bahwa hasil belajar bahasa Indonesia pada siklus II mengalami peningkatan dan hasil ketuntasan belajar siswa kelas V SDN 007 Samarinda Ulu telah mencapai $80 \%$. Dari hasil tersebut peneliti menyatakan berhasil dan penelitian pun dihentikan.

Telah terjadi tindakan pada siklus I yang dilaksanakan sebanyak tiga kali pertemuan, dua kali pertemuan untuk mengajarkan materi dan pertemuan ketiga untuk melaksanakan tes. Selama pembelajaran ada beberapa masalah dan kendala yang dihadapi pada siklus I siswa masih banyak bercerita di dalam kelas, tidak memperhatikan penjelasan guru, berjalan-jalan ke tempat duduk temannya. Pada saat guru menjelaskan 
complette sentence dan kontrak pembelajaran kelas sedikit ribut sehingga situasi kelas menjadi ramai. Sementara itu, sebanyak 5 orang siswa lainnya sibuk bercerita dengan temannya. Lalu ada beberapa siswa yang masih kebingungan dalam pembelajaran dengan menggunakan complette sentence sehingga membutuhkan waktu dalam menjelaskannya.

Pada pertemuan kedua siklus satu, guru kembali menggunkan complette sentence untuk menarik minat belajar dan motivasi belajar siswa dalam mengikuti pembelajaran dengan membagi beberapa kelompok untuk melakukan kegiatan dengan complette sentence. Namun masih ditemui hal yang sama seperti pertemuan pertama. Pertemuan terakhir atau ketiga siklus satu ini guru mengulang kembali materi yang disampaikan pada siklus satu dan dua sebelum melakukan tes.

Data nilai semester I (prasiklus) siswa kelas III yang peneliti peroleh dari wali kelas III menunjukan bahwa proses pembelajaran terganggu oleh lingkungan sekolah yang berdekatan dengan rumah penduduk. Hal ini yang membuat siswa kurang tertarik untuk belajar. Sedangkan pada siklus I peneliti menggunakan complette sentence. Ini menjadikan siswa tertarik belajar dan termotivasi terlihat dari data siklus I membuktikan bahwa menggunakan complette sentence efektif menarik minat belajar dan motivasi siswa khususnya pembelajaran muatan bahasa Indonesia.

Pada prasiklus dan siklus I mengalami peningkatan ketuntasan. Pada prasiklus hanya 10 orang siswa yang tuntas dan 20 orang siswa tidak tuntas karena tidak mencapai kriteria ketuntasan minimum (KKM) dalam pembelajaran muatan bahasa Indonesia. Pada siklus I siswa yang tuntas lebih banyak dari pada yang tidak tuntas. Hal ini dikarenakan pada siklus I menggunakan complette sentence yang menarik perhatian siswa untuk belajar dan termotivasi sehingga siswa mudah memahami materi yang disampaikan.

Tindakan pada siklus II dilaksanakan sebanyak tiga kali pertemuan, dua kali pertemuan untuk mengajarkan materi dan pertemuan ketiga untuk melaksanakan tes. Selama pelaksanaan pembelajaran berlangsung terdapat beberapa masalah yang dihadapi peneliti. Adapun masalah tersebut yaitu masih ada beberapa siswa yang sibuk berbicara dengan temannya. Namun pada siklus II ini siswa terlihat lebih aktif dan siap mengikuti pembelajaran. Pada saat guru memulai pembelajaran terlihat siswa berminat dan termotivasi mengikuti kegiatan pembelajaran dan terlihat lebih siap mengikuti pembelajaran.

Pada pertemuan kedua siklus kedua dilaksanakan guru melanjutkan materi dari pertemuan pertama dengan menggunakan complette sentence. Siswa terlihat lebih siap mengikuti pembelajaran, siswa tidak mengalami kesulitan mengikuti complette sentence. Saat pertemuan ketiga pada siklus dua ini guru mengulang kembali materi yang disampaikan sebelunya. Hasil belajar siswa pada siklus II mencapai $80 \%$ dan dapat dikatakan bahwa pada siklus II telah mencapai keriterian ketuntasan minimum (KKM) yang diharapkan.

Berdasarkan hasil data yang telah diperoleh menunjukan semangat belajar siswa menjadi lebih baik pada mata pelajaran muatan bahasa Indonesia dengan menggunakan complette sentence. Hasil belajar siswa telah mencapai kriteria ketuntasan maksimal (KKM) yang telah ditetapkan yaitu 75 . Dari hasil yang diperoleh pada siklus II dapat dikatakan bahwa hasil belajar siswa dengan pembelajaran muatan Bahasa Indonesia telah meningkat.

\section{SIMPULAN}

Berdasarkan hasil penelitian dan pembahasan dapat disimpulkan bahwa pembelajaran muatan bahasa Indonesia 
menggunakan complette sentence dapat meningkatkan hasil belajar siswa kelas III SDN 027 Samarinda Ulu Tahun Pembelajaran 2019/2020. Hal ini dapat dilihat dari ketuntasan belajar pada siklus I dan siklus II dibandingkan dengan hasil observasi sebelum dilakukannya tindakan yaitu nilai semester I siswa kelas V SDN 007 Samarinda Ulu. Pada siklus I nilai ratarata 70 , kemudian sampai akhirnya meningkat pada siklus II menjadi 80 . Nilai rata-rata tersebut sudah melampaui kriteria ketuntasan minimum (KKM). Dengan demikian complette sentence dapat dinyatakan mampu meningkatkan hasil pembelajaran muatan bahasa Indonesia di kelas III SDN 027 Samarinda Ulu Tahun Pembelajaran 2019/2020.

Adapun saran yang dapat diberikan setelah melakukan mendapatkan hasil dalam penelitian tindakan kelas (PTK) ini adalah guru dapat menggunakan complette sentence dalam pembelajaran agar memunculkan hal yang menarik, aktif, dan kreatif sehingga dapat menciptakan rasa senang kepada anak dalam pembelajaran muatan Bahasa Indonesia. Selain itu, sekolah dapat mendukung kegiatan pembelajaran dengan menekankan penerapan pembelajaran yang lebih aktif, kreatif, dan bervariasi khususnya pada pembelajaran muatan bahasa Indonesia dengan menggunakan complette sentence.

\section{DAFTAR PUSTAKA}

Amiruno, \& Daryanto. (2016). Evaluasi dan Penilaian Pembelajaran Kurikulum 2013. Gava Media.

Anisatun, Nafi'ah S. (2018). Model Model Pembelajaran Bahasa Indonesia di SD/MI. Jogjakarta. Ar Ruzz Media.

Anshori, M., \& Iswati, S. (2019). Metodologi Penelitian Kuantitatif. Surabaya. Airlangga University Perss.
Aunurrahman. (2014). Belajar dan Pembelajaran. Bandung. Alfabeta.

Chomaidi, \& Salmah. (2018). Strategi Pembelajaran Sekolah. Jakarta. Grasindo Anggota Ikapi.

Dimyati, \& Mudjiono. (2015). Belajar dan Pembelajaran. Jakarta. Rineka Cipta.

Jalil, J. (2018). Pendidikan Karakter Implementasi Oleh Guru Kurikulum Sumber Daya Pendidikan. Jawa Barat. Jejak.

Jumaidi. (2018). Model Model Pembelajaran Kelompok Sistem Perilaku. Jogjakarta. UNY.

Malawi, I., Kadarwati, A., \& Permata, D. (2019). Teori dan Aplikasi Pembelajaran Terpadu. Jawa Timur. Ae Media Grafika.

Nurhafit, \& Kurniawan. (2017). Penelitian Tindakan Kelas. Jogjakarta. Deepublish.

Prastowo, A. (2019). Analisis Pembelajaran Tematik Terpadu. Jakarta. Kencana.

Rusman. (2014). Model Model Pembelajaran Mengembangkan Profesionalisme Guru. Jakarta. Rajawali Pers.

Shoimin, A. (2017). Model Pembelajaran Inovatif dalam Kurikulum 13. Jogjakarta. Ar Ruzz Media.

Suardi, M. (2018). Belajar dan Pembelajaran. Jogjakarta. Deepublish.

Subyantoro. (2019). Penelitian Tindakan Kelas Metode Kaidah Penulisan dan Publikasi. Depok. Rajawali Pers.

Sugiyono. (2018). Metode Penelitian Kuantitatif Kualitatif $R \& D$.

Bandung. Alfabeta.

Sugiyono. (2019). Metode Penelitian dan Pengembangan. Bandung. Alfabeta.

Tampubolon, S. (2014). Penelitian Tindakan Kelas untuk 
Pengembangan Profesi Pendidik

dan Keilmuan. Jakarta.

Erlangga.

Thobroni. (2015). Belajar dan

Pembelajaran Teori dan Praktik.

Jogjakarta. Ar Ruzz Media.

Trianto. (2011). Desain Pengembangan

Pembelajaran Tematik Bagi

Anak Usia Dini TK dan Anak

Kelas Awal SD/MI. Jakarta.

Kencana.

Yusuf, M. (2014). Metode Penelitian

Kuantitatif Kualitatif dan

Penelitian Gabungan. Jakarta.

Kencana.

Zahroh, A. (2015). Membangun Kualitas

Pembelajaran Melalui

Dimensi Profesionalisme Guru.

Bandung. Yrama Widya. 